\title{
Sustainability in the New Congo's Tropical Architecture: A Case Study of The Sabena Towers by Claude Laurens
}

\author{
Alexis Tshiunza ${ }^{1}$, Manlio Michieletto ${ }^{2} \&$ Olatunde Adedayo $^{2}$ \\ ${ }^{1}$ School of Architecture and Urban Planning, Kinshasa, DR Congo \\ ${ }^{2}$ School of Architecture and Built Environment, University of Rwanda, Kigali, Rwanda \\ Correspondence: Manlio Michieletto, School of Architecture and Built Environment, University of Rwanda, \\ Kigali, Rwanda. Tel: 250-782-331-016. E-mail: m.manlio@ur.ac.rw
}

Received: August 11, 2021 Accepted: August 16, $2021 \quad$ Online Published: September 2, 2021

\begin{abstract}
Tropicalizing a building might seem like the best option for a young architect who lands in the tropics, but this is an approach contrary to sustainability. Claude Laurens, through one of his first projects in Congo, understood that it was better to deal with the place from the start. His project became one of the best examples of tropical modernism. The article attempts to contrast an import approach with a more sustainable one, to deal with the present and future context. The research method adopted for this study was a mixed method approach where data was sourced from literature as secondary source and compared with direct observation of the selected case study (The Sabena Towers). The results are presented as figures which were used to further illustrate findings. The result showed that the architect, with little information, did his utmost to offer Congo a new architecture that fitted with the objectives of sustainable development. The study concluded that the architect chose not to adopt the foreign architecture as a solution for the sustainability issues he encountered in the design, rather he evolved solutions that were Congolese based and therefore responded adequately to the challenges of sustainability in Congo and created an architecture for Congo.
\end{abstract}

Keywords: Congo, tropical architecture, tropical modernism, sustainability

\section{Introduction}

The capital of the Belgian Congo was transferred from Boma to Léopoldville (Kinshasa). The population of the city had been on the rise before the decision was taken in 1923, it is important to note that the capital Kinshasa has not stopped growing till date. The growing population as a result of migration, the attendant increase in business growth of the city and its strategic position have ended up making the city of Kinshasa an essential point in transportation discuss in Congo. The factors enumerated have had a significant impact on the city development with the railway been moved away from its initial location and replaced with a boulevard that ran parallel to the river. An examination of the development pattern along the river showed that the first institutions based along the river had taken all the places and the new ones were starting to move towards this boulevard to set up offices, agencies and housing.

A common challenge with population increase in any city or urban is the demand for housing and this was the case with Kinshasa. All the companies and factories needed labour which was met with the migration of labour into the city and very quickly the housing problem arose in the capital, especially for the locals who could not afford the cost. Companies were initially encouraged to set up workers' camps, but the demand was very high. The haphazard solutions and self-help created by the inhabitants of the city created several problems for the city and this problem required a well thought out plan. The solution to curb the deteriorating nature of the city was to create a dignified capital with a new development plan. It was based on this desire that the first ten-year plan for the economic and social development of the Belgian Congo was designed in 1949. The challenge for architects is to participate in sustainable development without losing the overall aim of the city development and growth.

In order to participate adequately in sustainable development, it is very important to be able to examine the underlining changes that have occurred in that society. In the case of Congo there was distinct change in two moments.

The first was the arrival of architects in the Belgian colony. It marked the end of prefabricated constructions and a definition of the colonial genre which was around the 1920s. In the Congo, Gaston Boghemans was the first to 
succeed in gaining a reputation as an architect and spreading the message of the types of building and the materials needed (Pinol, 2003). It is important to note that around this period in 1920s Léopoldville was called the capital of the Congo and it was important to reflect on how to build the new city (Heymans, 1949).

Boghemans was the head of the town planning department for the Colony. He wrote the book "COLONIAL HOUSING - SA CONSTRUCTION AU CONGO BELGE" in 1921. He collected the broad outlines on the overall layout, shape, dimensions, comfort and hygiene. He advised certain provisions which will quickly became null and void when Laurens arrived in the Congo. The advices Boghemans gave in particular were:

- Choose an elevated site to avoid the too frequent marshes in the Congo, the mist in the valleys and take full advantage of the breeze (wind).

- Colonial constructions must be simple, both owing to the lack of skill of the black labour force and for reasons of economy.

- The pieces must be large, that is $5 \times 5$ and the height greater than 4 meters. This requires large plots.

- The 2.5 to 3 metres veranda to protect the door and windows from the sun is ideal. It must be placed all around the house.

- It is desirable that the kitchen and the living space are not part of the main body of the building. They can be glued to the building without direct communication.

Boghemans' advice was appropriate during the formation of the capital, but the growing population and the cost of land in the city centre led to a review of the aforementioned arrangements. The second moment was the ten-year development plan where several young architects arrived in the colony. They found that it is possible to build anywhere. The first building, the Forescom, was able to be built in one year on sandy ground. The lack of skill in the workforce was questionable. Houyoux, who was among the first young architects, he is proud to have produced works with an essentially local workforce. With new knowledge, it was possible to obtain comfort in houses without the rooms being $25 \mathrm{~m}^{2}$ and $4 \mathrm{~m}$ high. The verandas were replaced and the water features were incorporated into the buildings. The development of the city requires mastering these changes and the desire to modernize. It was no longer a question of continuing the spreading out but of building vertical. How would the tropical tower look?

\subsection{The Sabena Towers and Laurens' Architectural Philosophy}

A few years after the construction of this towers, Claude Laurens recalls his approach: "In the Belgian Congo, as in other tropical regions of the world, the architect trained in Europe found himself faced with particular conditions very different from those of countries with a temperate climate. As a result, he must forget most the data learned, he must necessarily rethink the architectural problem, create something new for this new country if he wants to fully fulfil his role as an architect and accomplish a logical and sustainable work". (Laurens, 1957a)

If the plot was chosen with great care, it remained for the architect to enhance it. In the 1950s, not much about the tropical climate was known by architects. Architects had to educate themselves on almost everything. Claude Laurens knew what to expect, he did not think of copying European buildings and then trying to tropicalize them. $\mathrm{He}$ had to "forget the data learned in Europe and study on the spot the conditions specific to the region" (Lagae \& Laurens, 2001). "He had to study the climate of the region as a must himself to determine where he was to build, taking into account the data of heat, humidity, rainfall, sunshine, temperature differences, violent atmospheric phenomena such as tornadoes" (Laurens, 1957a).

Since he could not import from Europe, Laurens was interested in Brazilian architecture which was made in the tropics, with many similarities. The driving philosophy was captured in this statement:

"We need to create an architecture that perfectly meets the needs of the white man and minimizes for him the disadvantages of a hostile climate. This architecture will be truly Congolese, it will be beautiful because it is logical and well suited to the special living conditions of modern man in Africa. "(Laurens, 1953)

\section{Method}

The cited publications date from the years of the construction of the towers, this article can be considered as historical research. The research method adopted for this study was a mix method, a combination of review of historical data and records with direct observation of the variable in selected case studies. The architect's statements formed the basis of this reflection. In the absence of several critical studies, a comparison of these statements with an observation of the buildings was necessary to draw results. 
The Sabena Towers were selected as a case study because they were the most significant buildings in Laurens. They are located on the main artery of the city, the Boulevard du 30 Juin and not far from the monumental axis, designed to accommodate the most important projects. These towers are a good illustration of the effort to build for a developing city, respecting the climate and thinking about the future, especially in the choice of materials. The study examined variables that related to related to sustainability right from the choice of the site to orientation and design choices. These variables were discussed and the design principle underpinning them were studied. The use of pictures and figures were to further illustrate the points made by the architect regarding the provisions for sustainability.

\section{Analysis and Results}

\subsection{Climate Responses}

The growth of Kinshasa was such that business were springing up and taking up any available office or housing for the staff. The challenge was businesses to find the right office space and housing that would suit their growing staff requirement, just like these other businesses, businesses, Sabena needed offices and housing for its workers. West Leopoldville, with its flourishing business, was chosen for offices location while Kalina, administrative centre, was preferred for housing location. A major attracting factor was that several buildings were under construction there to house state officials.

The land was carefully chosen. It is located not far from the dominion axis in a triangle formed by the boulevard du Albert 1er (current boulevard du 30 Juin), avenue Prince de Liège (current high command), one of the first to be paved and avenue Palmier. The junction of the Dominion axis with Boulevard Albert 1er was provided for in Georges Ricquier's plan as shown in figure 1 and several projects are being added to the neighbourhood to benefit from all the expected facilities, including a cultural centre.

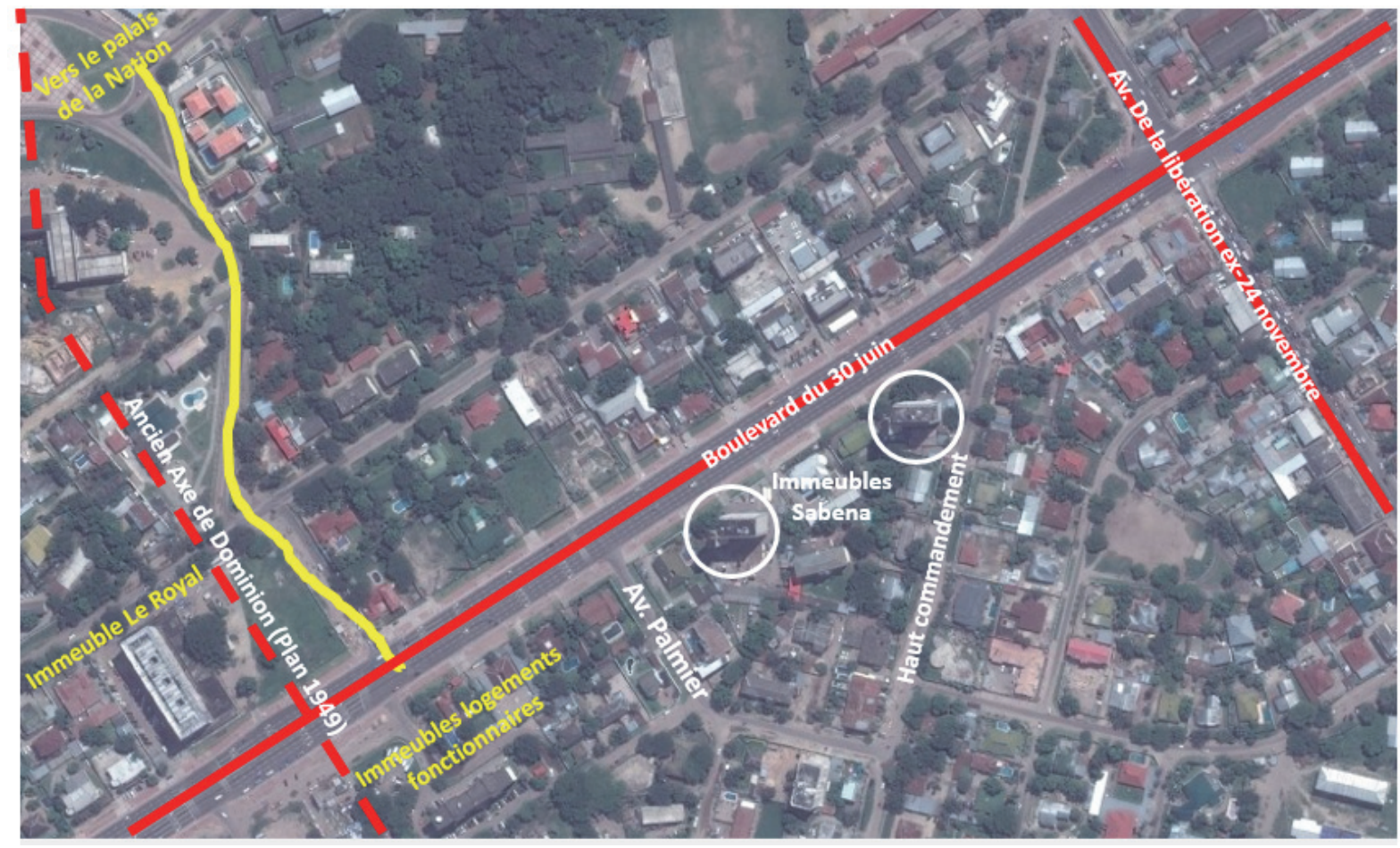

Figure 1. Location of Sabena Towers. Source: Tshiunza (2020)

Right on the direction of what was to be the Dominion Axis is the Royal (1955-1957) residential building immediately after the SABENA Towers (1952-1954). The adjacent plot, is currently occupied by the government building, a second similar building was to be constructed. Opposite, on the boulevard, in a park, there were eight seven-story buildings built between 1951 and 1952, with twenty-eight apartments each, to house state officials. The neighbourhood would be a high value residential area considering the calibre of people expected live within the community in figure 2. There was therefore no question regarding the design approach towards housing, despite the local tradition of suburban buildings, of making bungalows. 


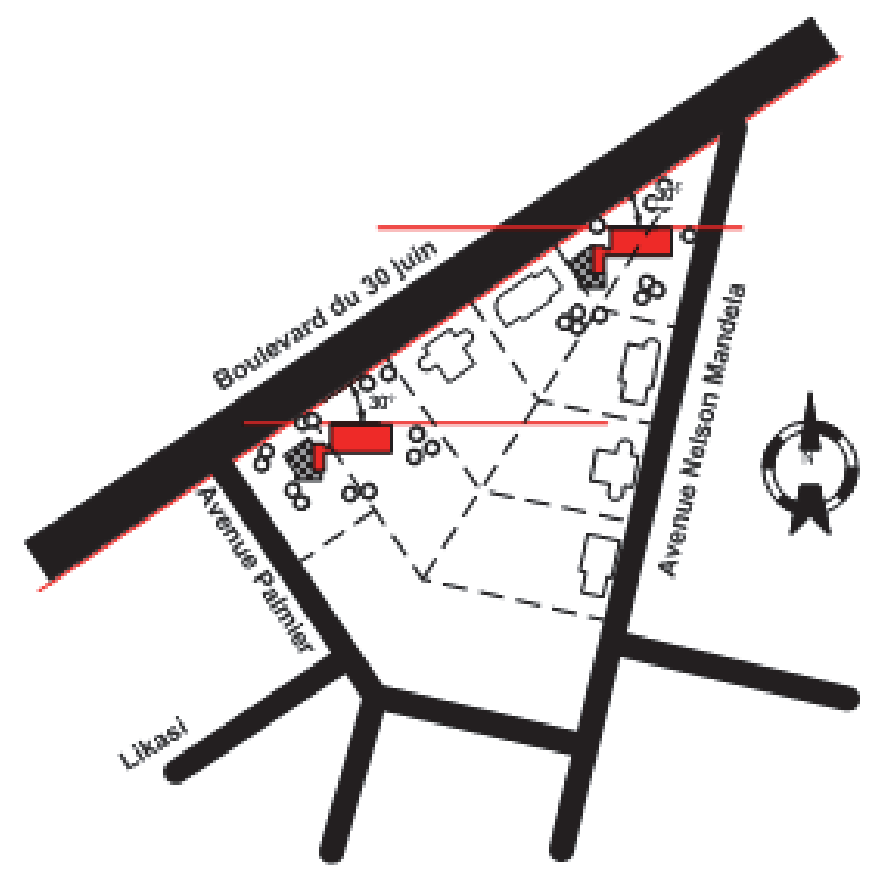

Figure 2. Site layout with the main axis of the towers oriented east-west. Source: Tshiunza (2020)

It is true that the architect of the civil servants' buildings opposite the Royal building had already tilted two buildings by following the orientation. This was not that remarkable as he had fielded the first 6 , before making such a decision for the last two which were hidden in the park. Laurens did it on the boulevard, showing indisputably that, in his hierarchy, the place was even more important than the route.

\subsection{The Orientation}

The major issue when considering orientation as a factor towards a sustainable design is often the issues associated with placement of windows and their sizes. According to Liébard \& De Herde (2003), the bay windows should be in the shade. When light enters the room directly, in addition to heat, it can dazzle. This should be avoided but will preserve natural light. The greenhouse effect would be avoided in particular, by not having windows exposed to the sun. The size, position and proportions of the windows are important because they do not only regulate ventilation but also light.

Laurens favoured the less sunny orientations hence he chose to have the openings of the rooms are oriented strictly north and south. They thus allowed rooms to keep their freshness because they do not receive direct radiation. He placed large windows that the occupants can open either fully or partially depending on the temperature and the wind. This was also in keeping with the culture of the tropics where one lived with doors and windows open (Boghemans, 1921).

\subsection{The Pilotis}

The architect put his buildings on stilts. The principle in play is that when two buildings are identical, one that is raised more than 1.5 meters will be better ventilated. (Dequeker \& Kanene, 1992). The raising of the foundation or the construction on stilts allows good ventilation and also participates in climatic town planning by not blocking the passage of air to neighbouring buildings.

He explained that "the free ground floor allows air to circulate normally and even creates a flow of air from the cold facades to the warm ones" (Lagae \& Laurens, 2001). In addition, the stilts keep the building away from noise nuisance and certain low-flying insects. Finally, Claude Laurens was able to take advantage of the vacuum created by using it as a vehicle parking space as shown in figure 3 . 


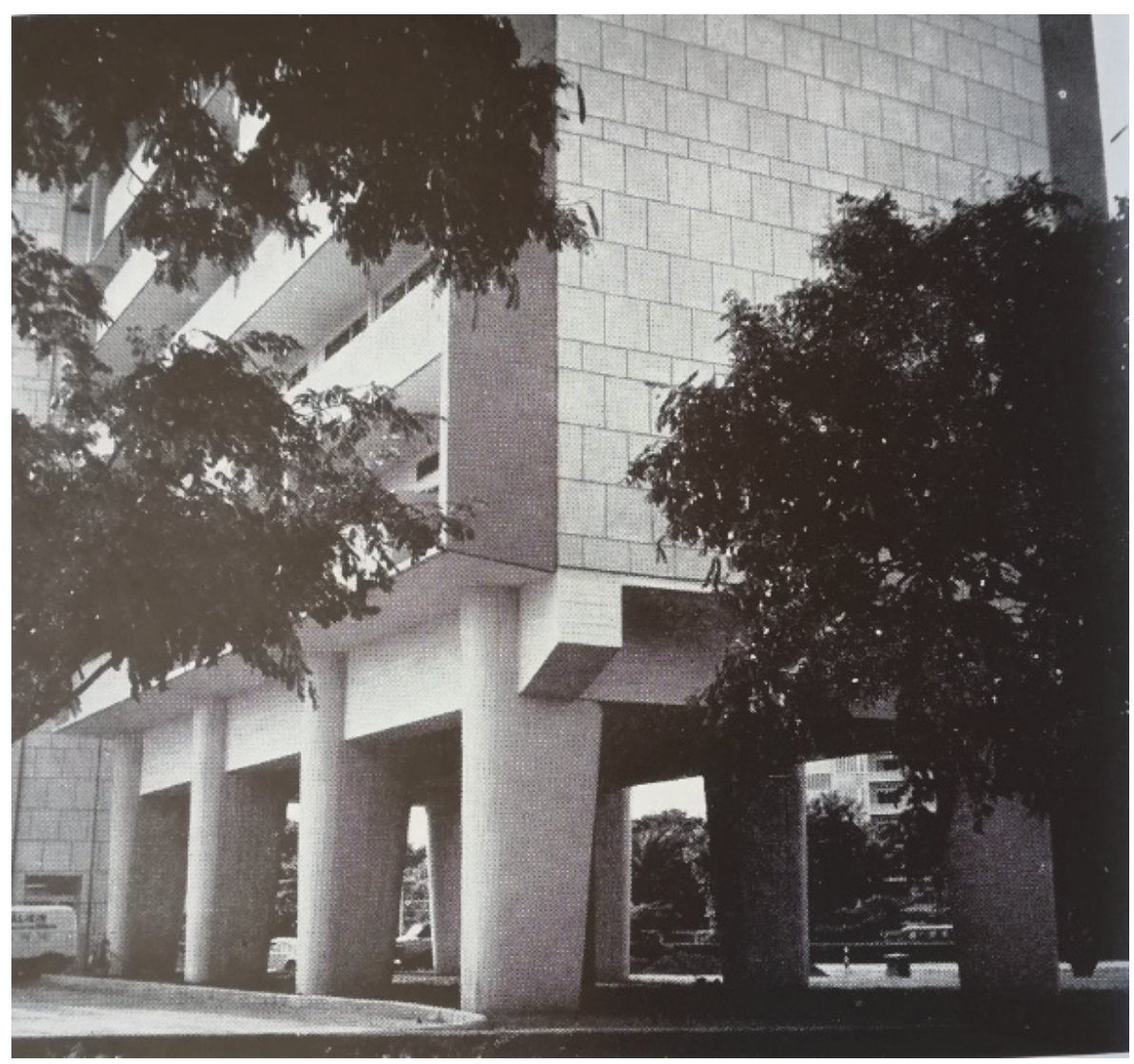

Figure 3. The towers built over the pilotis. Source: Fahrni (1959)

Radiation reverberation is a major difficulty in hot countries. The rays which strike the ground are reflected towards the building (Bruyère, 1952). The advice to raise the building and add plants around the building, or, when this is not possible, to lay a dark coloured floor covering. All these difficulties no longer arise if the building is raised or on stilts. This decision is ideal for tropical countries, for the same reasons (overheating by reverberation, insect nuisance and maximum ventilation necessary for the grain), the granaries as shown in figure 4 were almost always on stilts (Wauters, 1893). 


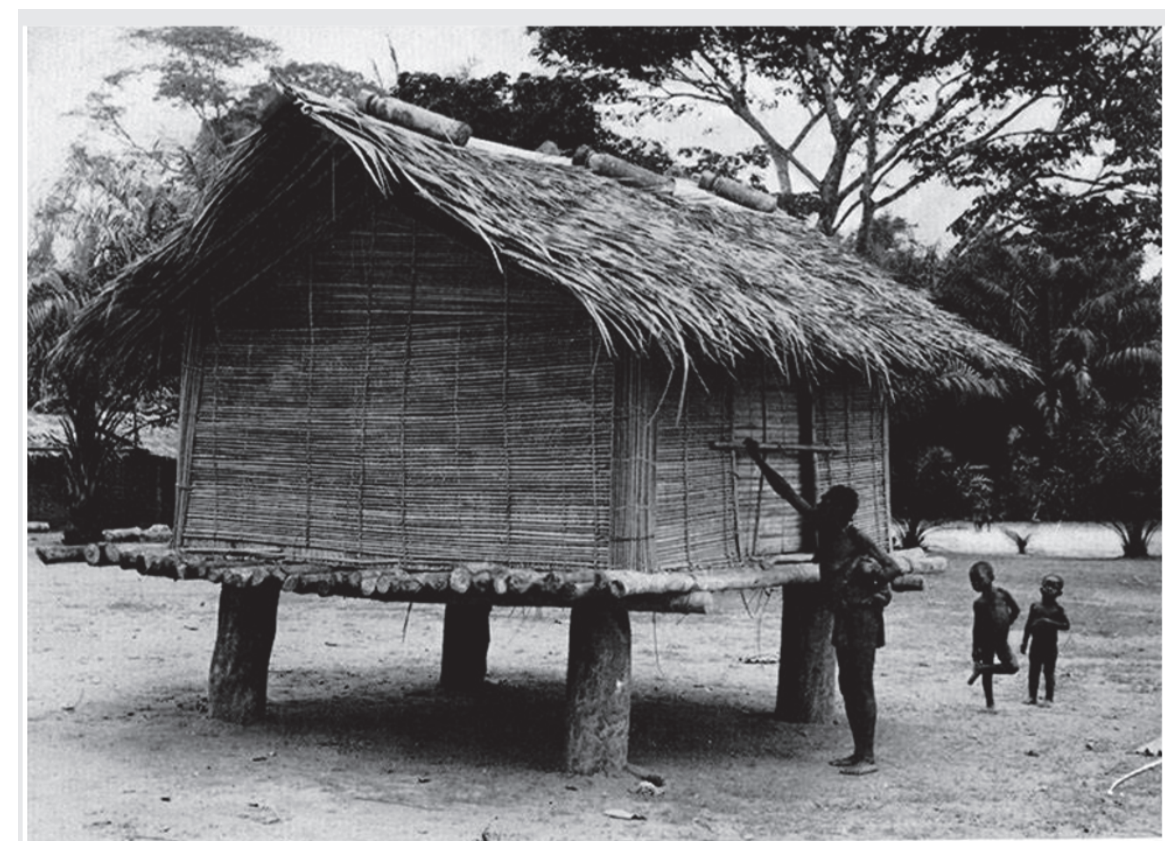

Figure 4. Granary on pilotis. Source: Guide du voyageur au Congo Belge (1958)

Piles are not, in this tradition of raised granaries, a foundation for a specific type of soil (often slippery or marshy) but the response to a climate and uses.

\subsection{The Treatment of Facades}

The facades of Laurens were not alike, Olgyay (1963), asserts that in all latitudes (in the West), the north receives the least heat. It is the opposite in the countries of the South. The north facade of the building will therefore be more protected than the south one and more open for ventilation. Laurens placed trellises there at half of the terraces while the south terraces are low walls. He added the solar shades, absent to the south.

Corollary to the very good orientation, the east and west facades are blind. Sun visors are generally ineffective in protecting them (Liébard \& De Herde, 2003). Without a neighbouring building that could act as a screen, only the slats inclined at $45^{\circ}$ and successive could leave a few openings. In this case, the facades do not offer a view of the landscapes. Laurens only used this solution in extreme cases (such as in the CMK building). These most exposed facades are in white to better reflect the light and accumulate less heat. For those who are less, Laurens chose a range of colours, a polychrome which had more impact in the aesthetic considerations.

\subsection{The Brise-Soleil and the Claustras}

The course of the sun in Kinshasa is not same as at the equator line. The slight inclination means that even with a perfect orientation, we need solar shades and slats on the north and sometimes south facades. The combination of vertical and horizontal projections offers better protection against the sun in this case (Liébard \& De Herde, 2003) and manages its beneficial contributions. The architects have at their disposal a very varied range of preconceived solutions including awnings, ailerons or pivoting sunshades, concrete slats, vertical, horizontal, in steps, structures forming a second skin, bow windows, shutters, awnings to hide the sun as seen in figure 5 . 

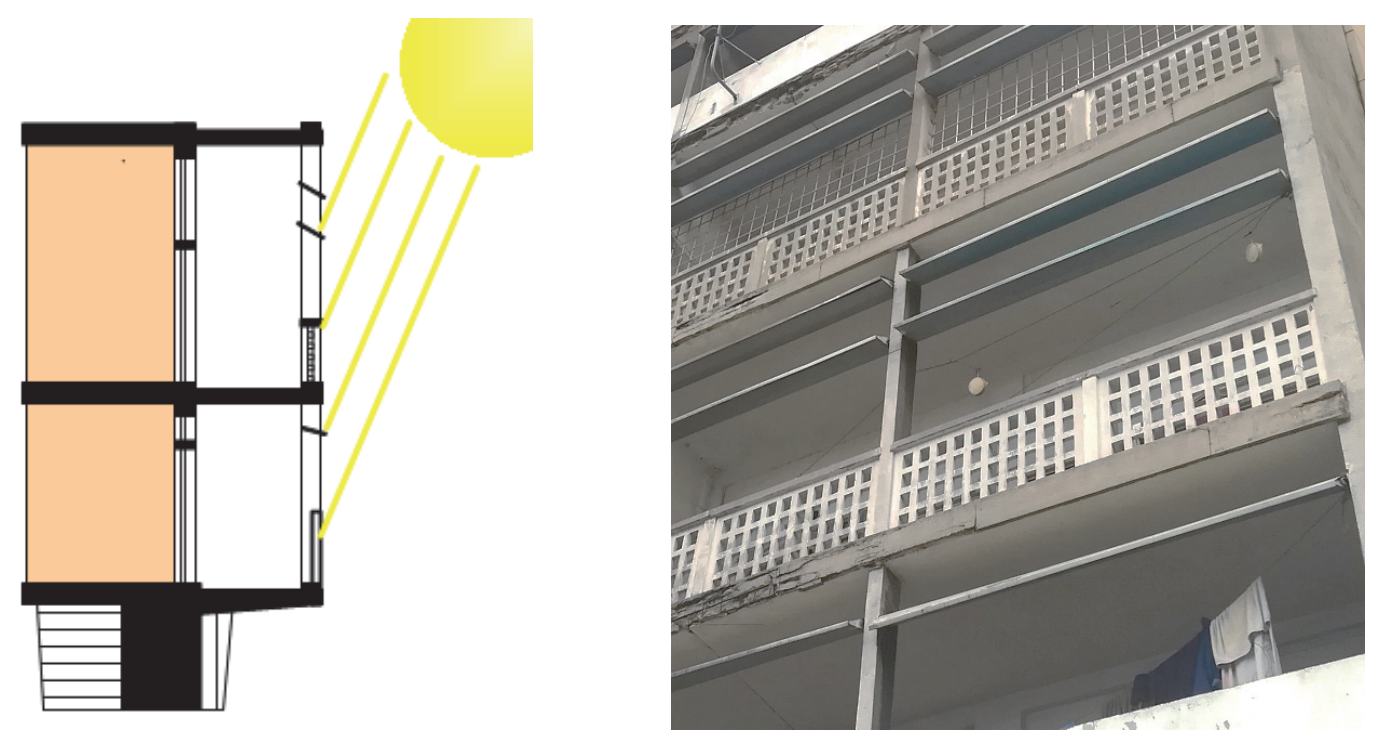

Figure 51. Brise-soleil on the Sabena towers elevations. Source: drawing and picture. Tshiunza (2020)

Claude Laurens had fun combining them during his career in the Congo. In its architecture, the sunshades became decorative elements, bringing a particular design and making tropical architecture a real style. In the towers, the vertical elements punctuated the facade, and carried a few inclined horizontal sunshades to respect the constraint of letting air pass and obscuring the sun. The architect justified this choice when he stated that: "As much as possible the sun shades protect facades exposed to a large number of hours of sunlight are mobile and made of thin sheets of aluminium, so as to prevent heat storage" as shown in figure 6 (Laurens, 1957a).

He also used trellises, these are, in reality, a form of solar shading and perhaps the best. They break the sun both vertically and horizontally while not blocking ventilation. They are small bow windows. Claude Laurens used them both on the terraces to form guardrails and in the vertical circulation hopper to avoid placing the windows but to obtain light and ventilation.

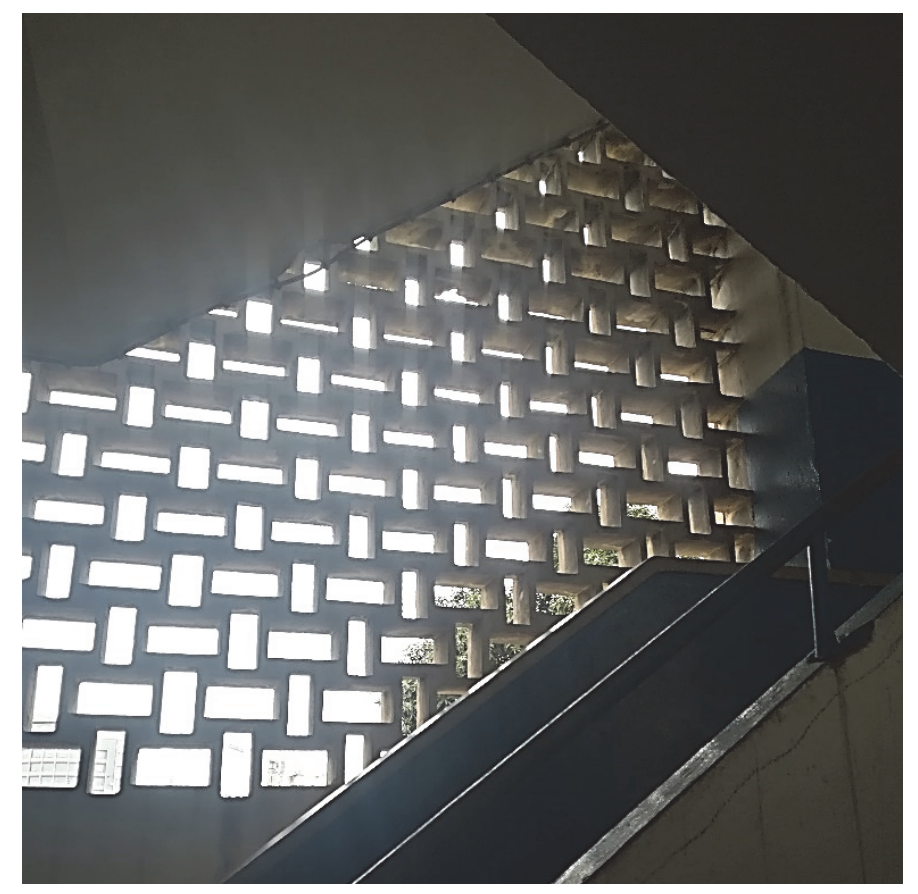

Figure 6. Perforated wall in the Sabena towers. Source: Tshiunza (2018) 
Solar shades are not placed in tropical Africa like elsewhere, that is to say, never close to the window nor indoors. A good distance between the solar shades and the windows must be maintained in order to have sufficient air between the two and to prevent them from constituting in turn a source of heat gain (Olgyay, 1963). Claude Laurens therefore naturally moved away his solar shading.

In addition, the trellises are in a tradition of hot countries. They are similar to the Moucharabiehs of the Magrebian countries, to the Jaalis in India, to the walls of walls made of weaving. Victor Olgyay thought that "the solar shades could express a strong spatial character, added new elements to an architectural vocabulary and revealed a true regional consciousness" (Olgyay, 1963).

\subsection{The Terraces and the Loggias}

Overhangs made it possible to manage natural lighting (Liébard \& De Herde, 2003). In order to achieve this, Laurens created semi-open spaces reminiscent of verandas and allowed for rooms that were not directly exposed to the sun to have semblance of it. It benefited from it on the rear facade as circulation, one level in two as presented in figure 7. Loggias appearing as alveoli made it possible to solve the problem of the quenching verandas of which Spanner spoke (1932). Bruyère advised to maintain the composition reminiscent of the Barzas in order to be able to keep the windows open despite the rain (1952). Circulations were pushed outside as well as in the veranda house. (Sinou, 1993) as depicted in figure 8 and figure 9.
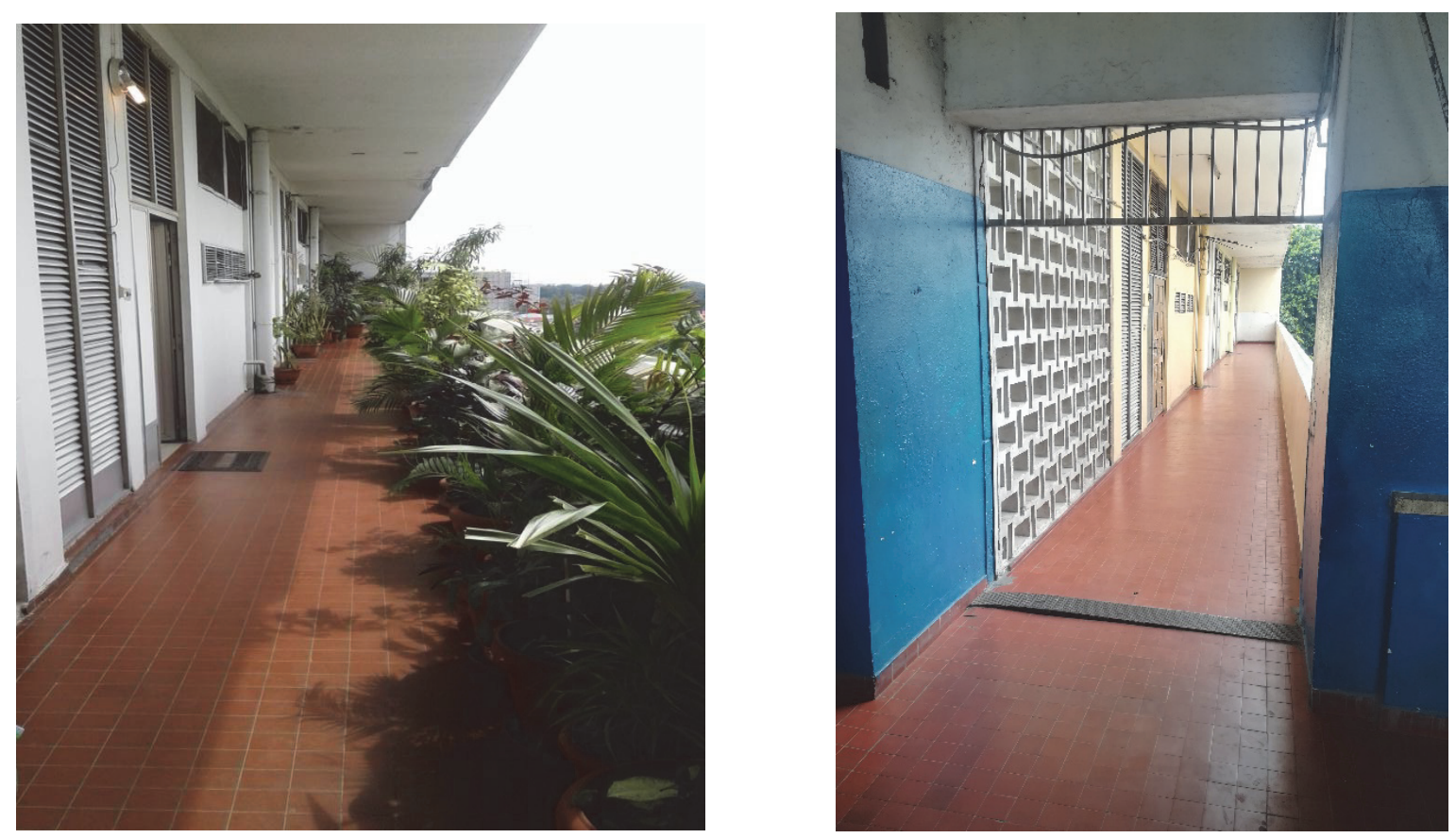

Figure 7. Circulation in the south elevation recalling the 'barza'. Source: Tshiunza (2018) 


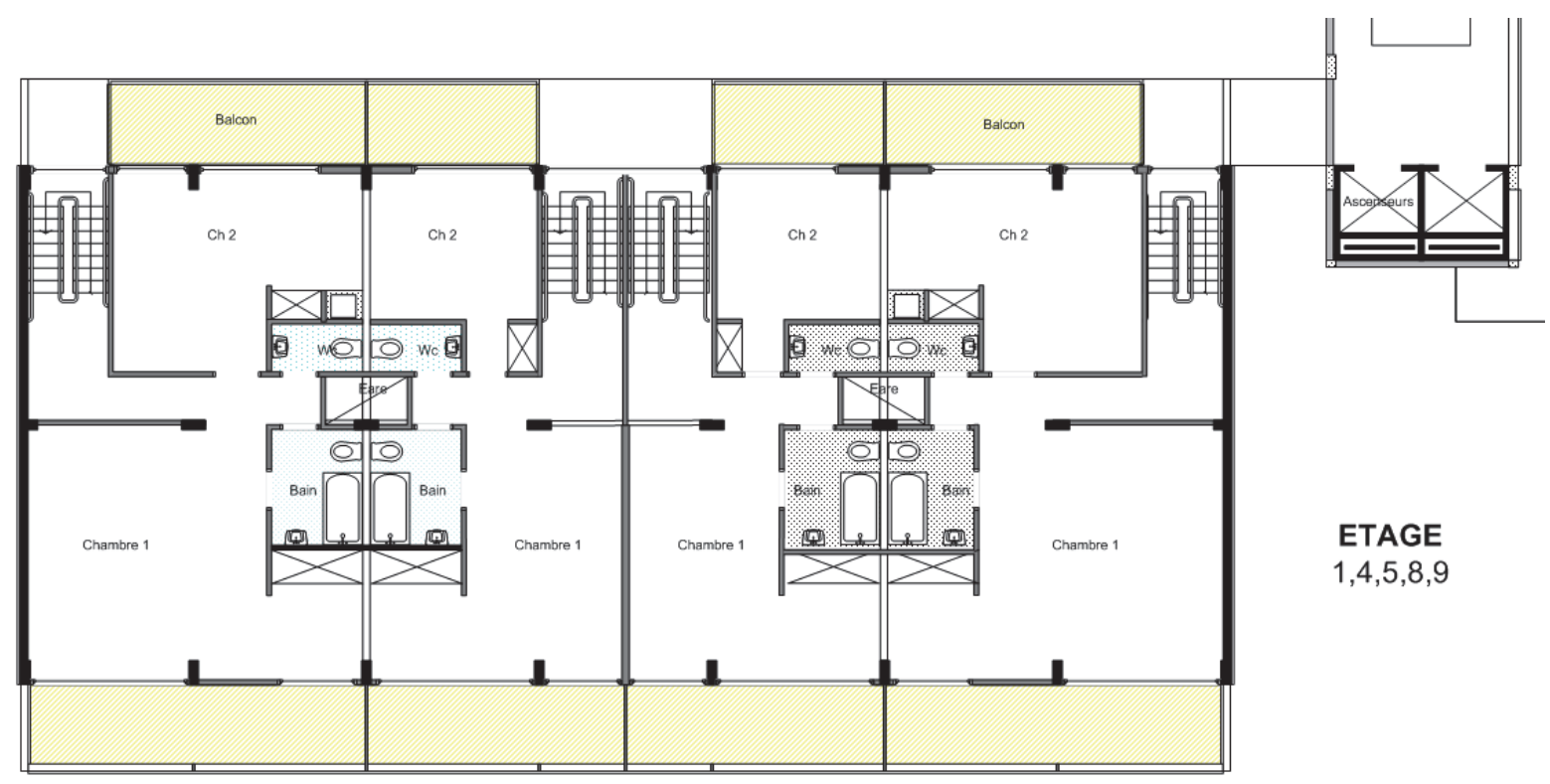

Figure 82. Plan view $1^{\text {st }}, 4^{\text {th }}, 5^{\text {th }}, 8^{\text {th }}$ and $9^{\text {th }}$ floor. Source: Tshiunza (2020)

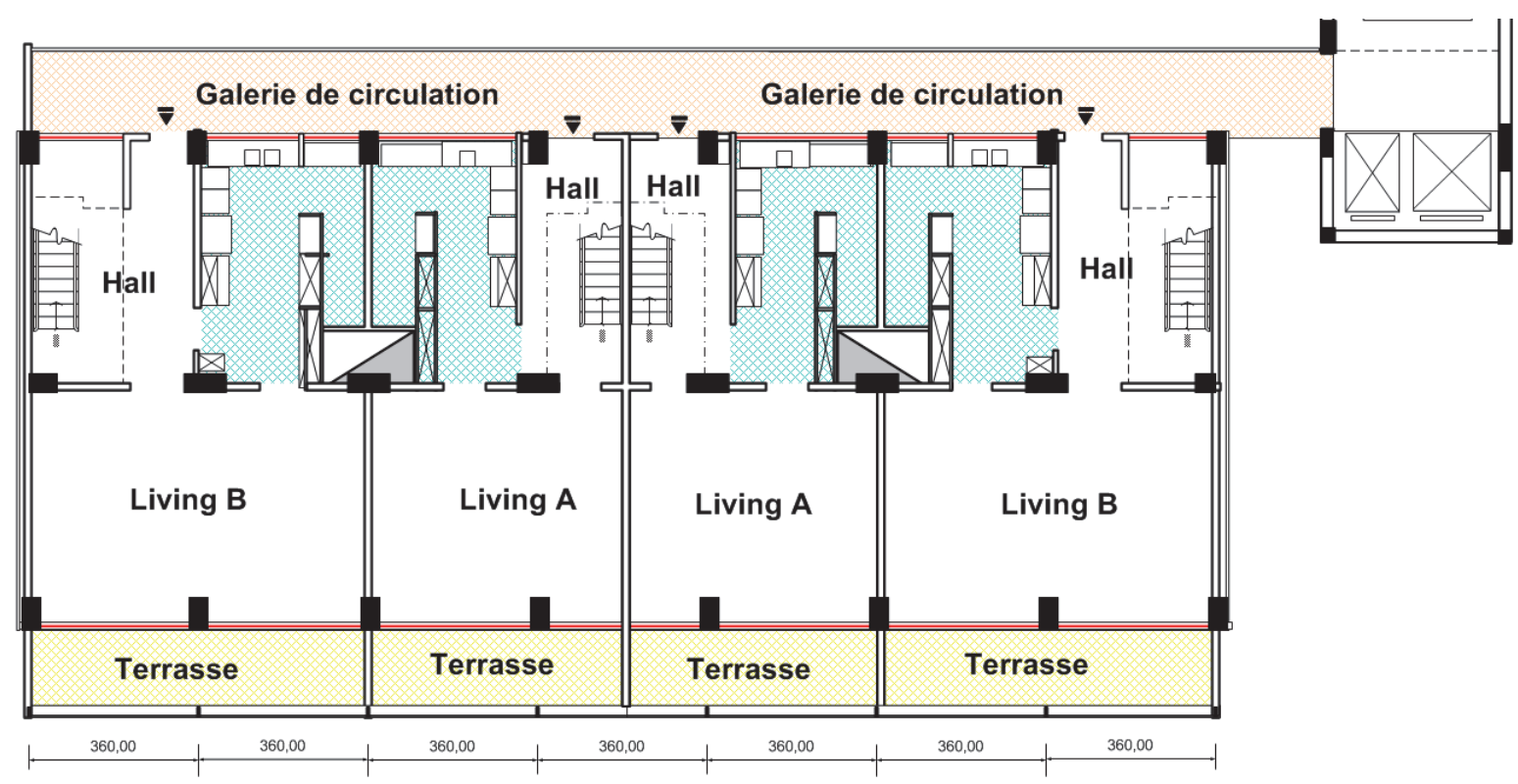

ETAGES 2, 3, 6, 7, 10

Figure 9. Plan view $2^{\text {nd }}, 3^{\text {rd }}, 7^{\text {th }}$ and $10^{\text {th }}$ floor. Source: Tshiunza (2020)

\subsection{The Ventilation}

The wind is an essentially a horizontal movement of air from a high pressure area to a low pressure area, the cross ventilation is from the facade in overpressure to that in depression (Liébard \& De Herde, 2003). Since the wind cannot always come from the same direction, windows are needed on the opposite sides so that the pressure difference between the exposed facades and the shaded ones promoted ventilation. Air circulation can be activated by the arrangement of the openings as well as by their size. In principle, when the openings are on opposite sides, the one through which the air enters should be smaller than the one at the outlet. This ventilation helps cool the spaces and the architect had done his best to optimize it. 


\subsection{Chimney Effect}

To ventilate the rooms that do not overlook the facades, Claude Laurens uses static ventilation, also known as the chimney effect. This is one of the justifications for piling. The architect placed a ventilation duct between two apartments. It started from the free ground floor and ended on the roof. The difference in density between cold air on the ground floor and warm air on the roof activates ventilation and became a solution (Dequeker \& Kanene, 1992).

\subsection{Materials and Sustainability}

Claude Laurens knew a lot about the materials he could use to build towers, he would have had to import them. The question of regionalism obliges it to limit itself to "the use of materials which are still in limited number at their disposal" (Laurens, 1957a). He had to also "study very closely the behaviour" (Laurens, 1957a) of these materials because "their behaviour would very often be different from that which they had in a temperate climate" (ibid.). Claude Laurens knew that the materials would not be chosen for the same reasons. They needed to be appropriate for a region to be used in. "Indeed," he said, "they would be subjected to massive solar action, continuous ambient humidity, torrential rains, and the attack of moulds and insects of all kinds" (ibid.). He had to choose them "according to their resistance to the very harsh conditions of the equatorial climate" (ibid.)

He eventually got an idea of suitable materials and would keep them for all his apartments or office buildings. These materials, in addition to being local and climate responsive, required "little or no maintenance". (Laurens, 1957a). The architect knew that this question would be essential in the life cycle of his buildings.

\subsection{The Concrete}

When Laurens built, there were already a lot of construction companies and it was easy to pour concrete in place. He made a real demonstration of it with his pilings which reflected all the daring and all the freedom of form that concrete could allow. It made all its structure before using other filling materials.

\subsection{Stones and Bricks}

Claude Laurens used all the materials that Houyoux had adopted from the Belgian Bank of Congo. It made extensive use of rubble stone for the entrance section that led upstairs. Bricks with honeycombs were used for the walls. The lightest possible walls whether inside apartments or outside was because of the climate. "Except those of the western facades which were double-walled with thermal insulation". (Laurens, 1957a)

\subsection{The Metal Elements}

The frames of the doors and windows were made of iron. The solar shades were made of anodically tinted blue aluminium. Several companies based in the Congo can provided all of the materials used. For the architect, the important thing was not so much that the material was produced but that they were marketed locally and suitable.

\subsection{The Façade Cladding System}

The walls captured the heat and returned it to the interior after phase shifting by reverberation. Sunscreens limited their exposure, ventilation limited heat build-up and thermal capacity limited overheating (Liébard \& De Herde, 2003). The choice of coating materials was essential and Laurens knew it. He chose quartz, which is white, as the exterior coverings to better reflect the sun's rays. Quartz is a good material that does not deteriorate over time. Its choice was therefore a very good thing in terms of sustainability. The plates used are in fact a mixture of concrete and local quartz grains. They did not require special care and were cleaned whenever it rained.

Insulation always plays a beneficial role: it cools the home by limiting heat input. Everyone had seen that a massive wall, sunny and well sheltered from the wind, remained warm long after sunset. Whether the construction is massive or light, the important thing was that the windows were in the shade and that there was ventilation. (Liébard \& De Herde, 2003). To avoid the reverberation due to the reflection of the sun on the spaces surrounding the panes, Laurens followed the well-known instruction of placing tiles of a dark colour on the floor (Bruyère, 1952). He chose a colour that Jacqmain would later call "African soil". He also used marble and ceramics, he carefully chose these materials that required the least amount of maintenance. On the question of materials, he favoured those that were local and sustainable.

\subsection{The Natural Environment}

The two buildings are built in a park. Tropical modernism gave pride of place to questions of nature. This vast space kept for vegetation had a direct impact on the climate around the building. Besides, the comfort that one could find in a box did not depend so much on it as on the environment in which it was found. Indeed, in the 
tropics, neighbouring buildings are not to be neglected. They can mask radiation and wind, thereby raising the outside temperature, or create drafts and reflect the sun as appropriate (Liébard \& De Herde, 2003). In 1952, Claude Laurens had no neighbour to fear in this sense.

The most remarkable aspect of the siting of the towers was the architect's decision not to line them up with the boulevard. It followed a recommendation from the 1932 Congress: "Arrange so that the largest facade of the houses is perpendicular to the direction of the prevailing south-westerly wind and not parallel to the street". He recommended that the buildings be sited as in a garden city ". (Royer, 1932)

\subsection{Le Social Involvement}

Bruyère wrote in 1951 that "Before the war, few large companies were established in the Congo; since 1945, a good number of Belgian firms had created a Congolese head office or were thinking of doing so, fortunately adding to the framework of local entrepreneurs". (Bruyère, 1952). "It therefore seemed that the technical conditions were met in the Belgian Congo to carry out a major construction program" (ibid. P.25). Already in 1949, Houyoux had built his bank bragging about having done so only with local labour. This would be the case with the Laurens building as shown in figure 10 .

Some of these workers would also build for the early black architects who considered tropical modernism to be their architecture. One of these architects became the first director general of the Institut Supérieur d'Architecture and participated in the construction of the buildings of the current institute with the great concern for transverse ventilation, orientation, the use of sun shades. Its design office was called "Tropique Architecture."

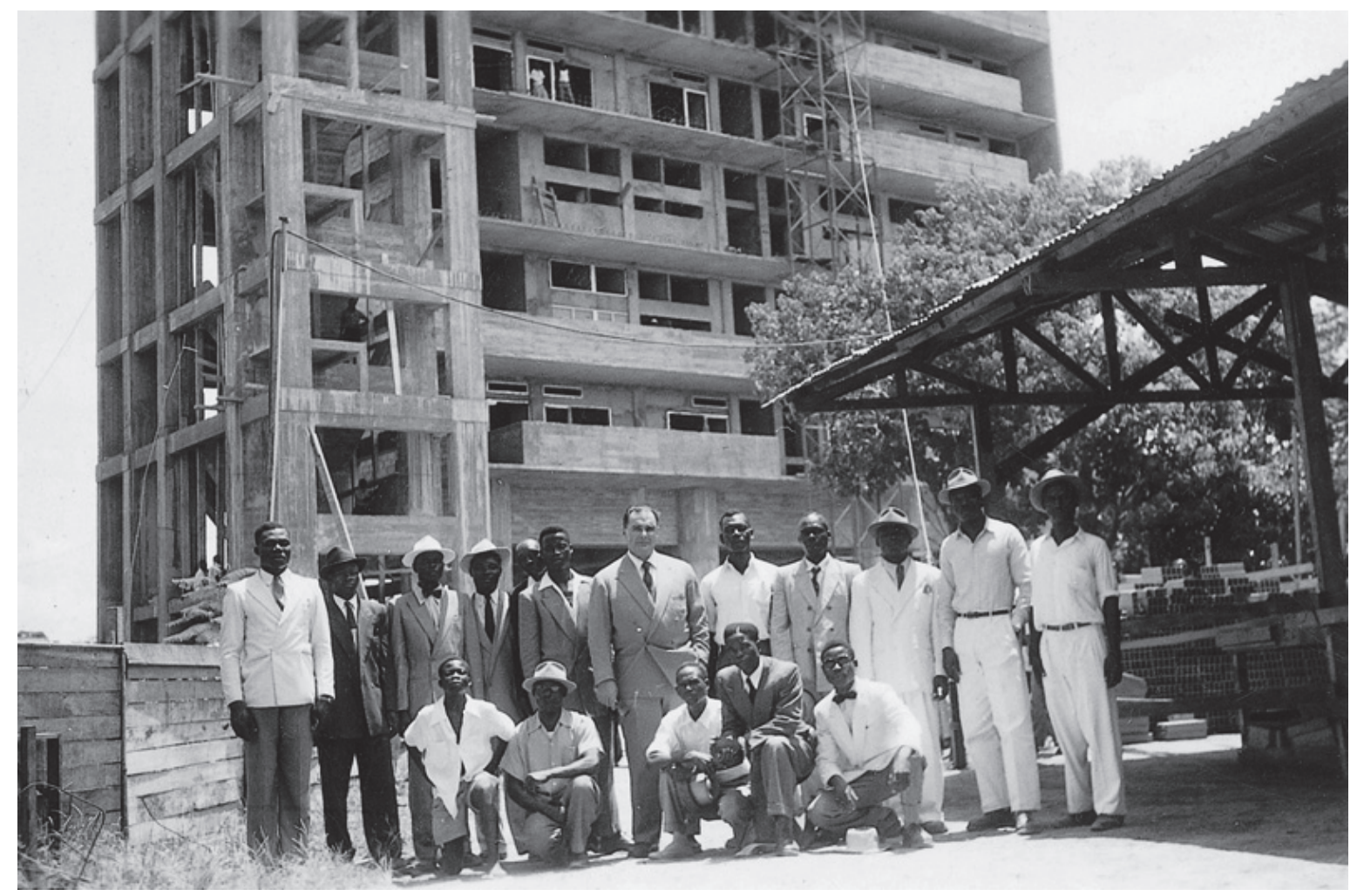

Figure 10. Claude Laurens with the local team in the site construction. Source: http://www.wikinshasa.org/images/2/28/018PH1.jpg

\subsection{The Aesthetic Aspects}

All the beauty is in the way a work is constructed not only in the spaces it offers, but also in the images it projects (McQuillan, 2016). The vertical elements constitute the frame and the horizontal ones mark each level. The structure of the building is clearly visible on all facades, even those with cladding. Most of the buildings built in the 1950s have the same coating, the quartz concrete slabs, placed in a grid, the tiles being of the same size and aligned both vertically and horizontally (opus reticulatum). Laurens buildings are considered as being 
special because, three or four large "opus quadratum" tiles mark each level, followed by a half-tile to emphasize the beam.

The major functions in the building is made easier to comprehend. The ground floor car park is on stilts. The bands in solid walls on the main facade are the floors of the bedrooms (A) which are 3 meters high, while the trellises indicated the levels of the living rooms (B) which are $375 \mathrm{~cm}$. Instead of a simple rhythm $\mathrm{AB}, \mathrm{AB}$, continuously, the architect does $\mathrm{AB}, \mathrm{BA}$, mixture. In the same way, it differentiated the rear facade, alternating for the living rooms the continuous bands up to the stairwell and the interrupted bands for the bedroom levels as shown in figure 11.
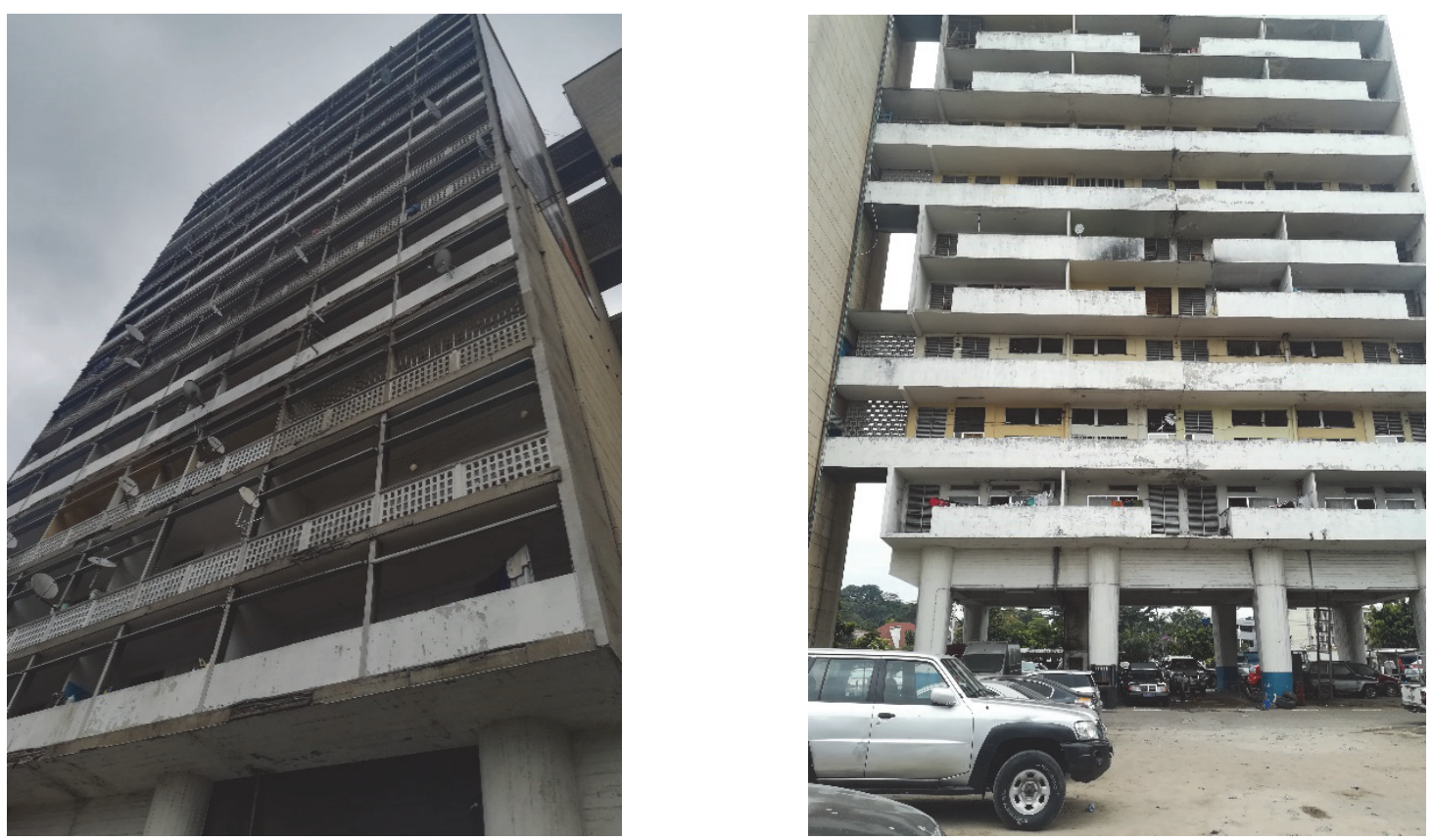

Figure 11. North and south elevations. Source: Tshiunza (2020)

On the side façades, it was observed that there four tiles for the living rooms and three for the bedrooms. The terraces and horizontal circulation are also legible; they do not have a quartz concrete coating. This is normal, because the areas were constantly ventilated. The architect also took care to differentiate the terraced screens from those of the vertical circulation. Small squares for the main facade and rectangles reminiscent of a weaving for the circulations as shown in figure 12 .
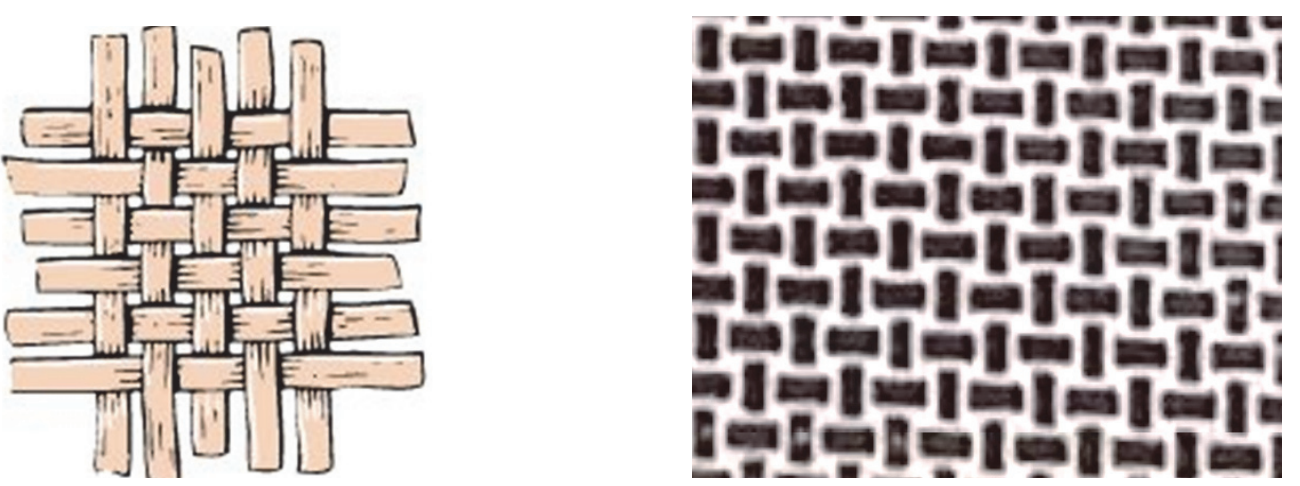

Figure 12. Perforated walls remind and allow porosity like weaving. Source: Tshiunza (2020)

The piles were expertly treated using the brutalist technique consisting of preserving the raw aspect of the concrete poured on site that is to say at the site. This concrete left uncoated showed all the traces of the 
formwork which was aesthetically placed to constitute a decorative motif. It is a synthesis of technique and aesthetics. This technique now bears the significant name of "architectural concrete" in the prefabricated industry. Laurens chose a pattern reminiscent of basketry as depicted in figure 13.

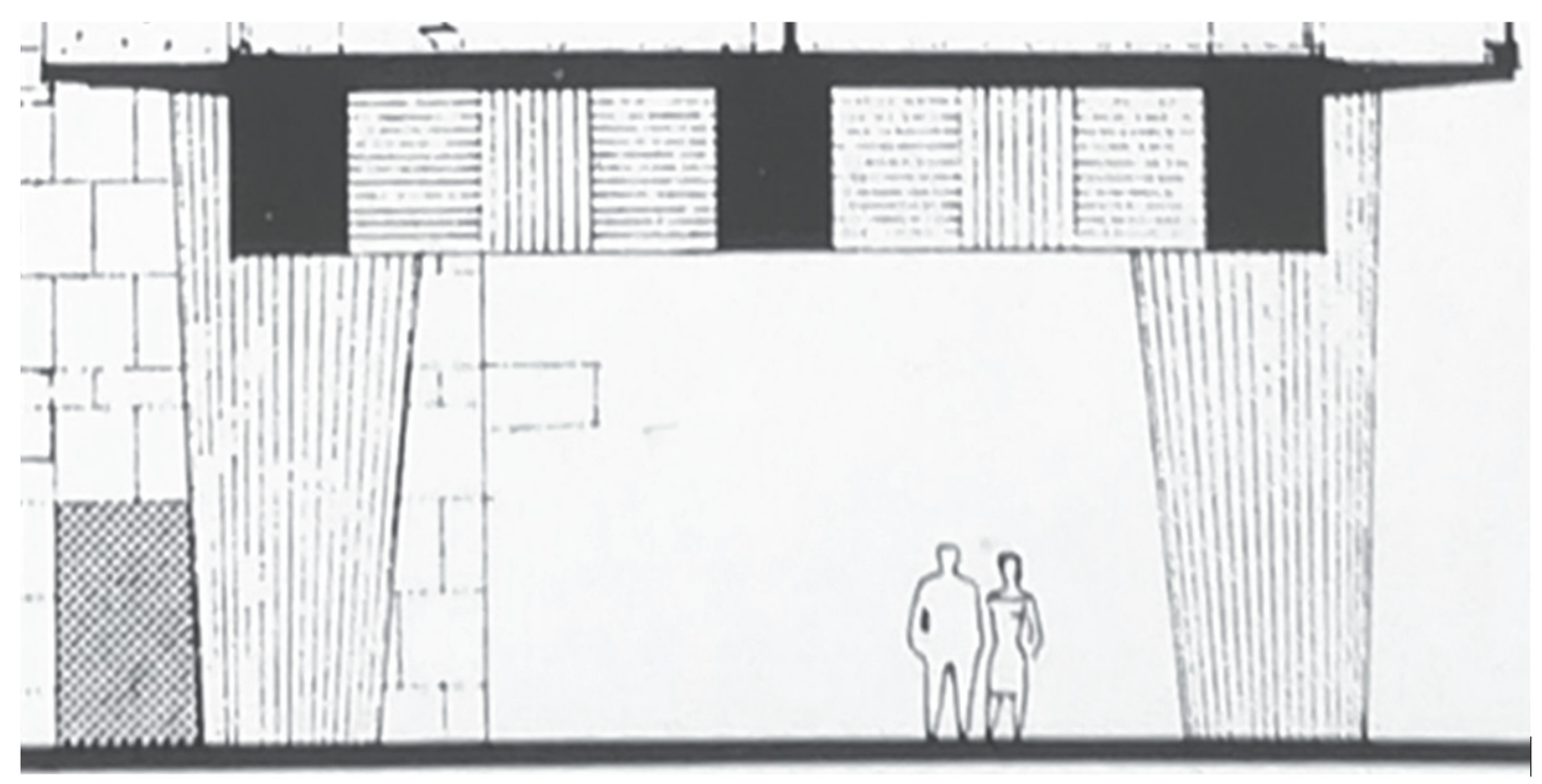

Figure 13. The architectural concrete patterns. Source: Architecture (1959, $\left.\mathrm{n}^{\circ} 27\right)$

The special attention to tectonics indicated that Laurens, even making buildings of very high plasticity, remained a rationalist. The tectonics gave a remarkable visual effect. The colour of the coating in quartz concrete slabs, white, certainly made it possible to reflect the light and therefore accumulated less heat which could be restored by reverberation. It also helped to make the building shine in the sun and to emphasize the shadows and the light. Claude Strebelle later said that details found in European architecture are devoured by light in Africa. "In this African nature we have an obligation to be simple, to be strong." (Hubin, 2002).

Laurens's buildings are photogenic and appeal to many architects who have never seen them face to face. They are considered as the object of colonial propaganda (see figure 14). There were several explanations offered regarding the choice of colours used on the building in figure 14 the thoughts behind the colour choices was explain as, "Where it was possible for him, the architect emphasized the volumes by the polychromic of the facades, blue, yellow, grey, red ochre were used" (Laurens, 1957). The colours in this building were not all linked to the climate. In order to ensure that his architecture was Congolese, the architect, who was undoubtedly aware of the importance of colours in the reflection of light, chose to paint blue, the horizontal solar shades on the main facade. The vertical divisions are in blue, yellow, grey and white. It is a known fact that, light colours reflect the sun's rays more than dark ones. Olgyay mentioned $85 \%$ reflection for polished aluminium, 71 for white, 50 for light green and 25 for grey and matte black comes last with 3\%. (Olgyay, 1963). Laurens still went ahead and chose for the solar shades "aluminium oxidized anodically in blue" (Lagae \& Laurens, 2001). One can speculate as to the reasons, but in fact two are obvious:

1. The reflection of the sun on metal is not pleasing to the eye.

2. It had other ranges of colour.

The Congo is blue as the Africanist painter Auguste Mambour thought: "The Congo is blue... This dominant colour is not an illusion of my eyes, but the exact reflection of reality. The Congo is blue" (Rycke, 1923) 

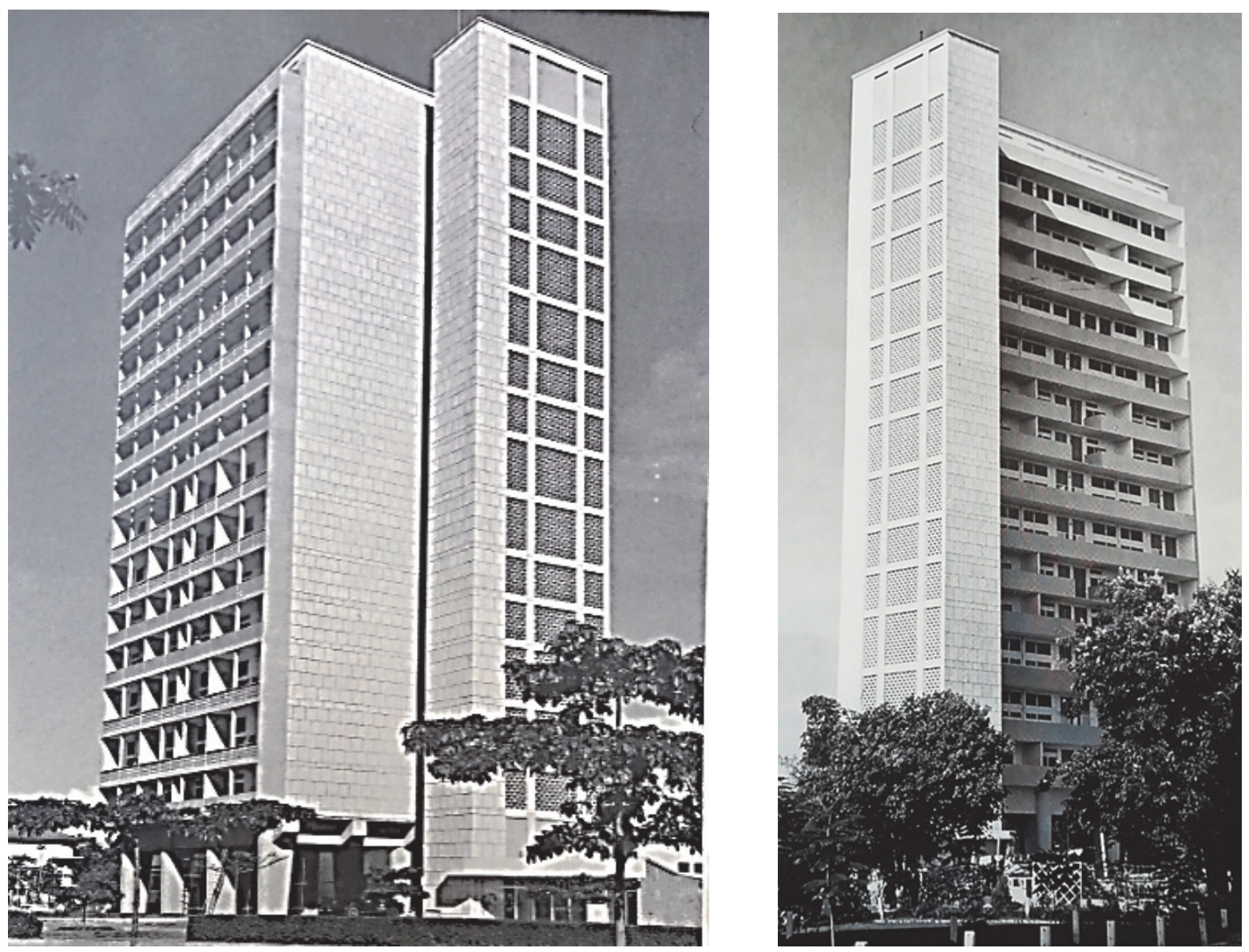

Figure 14. Shading on the north and south elevations. Source: Lagae \& Laurens (2001)

Indeed, "In the savannah areas, the sky is an intense blue," (Bruyère, 1952). "It is the perfect dissolution of the vapours in the air that must be attributed to the dark blue of the sky in the tropics. This dark sky is what strikes most travellers who arrive from the northern regions of Europe "(Lecoq, 1840). It is perhaps because of this colour that the flag of the Congo is blue. The major question in the mind of many who came in contact with the buildings of Laurens in Congo was: Did Laurens see the need to reflect the sky?

\section{Discussion}

A new urban architecture in Congo was necessary for the success of the ten-year plan for the Grand Léo and a new CONGO. Laurens hoped that "in the development of our time, the architecture of tropical regions would hold a very important place (Laurens, 1957a).

As an architect, Laurens produced a project that illustrated what a tropical tower could be. Instead of offering temporary solutions after designing imported buildings, the architect returned to the logic of architecture that emanates from the place. Its peculiarity was to orient the two towers strictly in relation to the cardinal points. He put them on stilts like African granaries and he also reinterpreted the barzas. Instead of internal circulation, the architect preferred duplex apartments, in order to allow access through passageways and with the loggias, they replaced the barzas. In addition to the architectural concrete pilings, the aesthetics of the building came from the rhythm of the terraces, either in clusters or in low walls. The wall covering was also rhythmic and the building was polychrome. The characteristic element of the tropical climate is blue, like the sky of the tropics. The architect predicted that his architecture would be truly Congolese base on some requirements which included: (1) Respect for the climate, (2) the choice of sustainable materials, (3) Integration into the environment, all these key factors made it a great lesson in sustainability.

\section{Conclusion}

Sustainability is a core issue that built environment professionals always seek to address, each time there is a new project or an opportunity to work on an existing project the issue of sustainability always comes to the fore. 
In the case of Congo, the need to ensure sustainability at a time when there was little or no relevant data for the architect to use, it was a major design challenge that had to be overcome. The architect was able to establish that the data from the developed country was not applicable in Congo given the differences in climatic and geographical location. The ability to identify the key sustainability issues that required attention was key to the success of the project. In achieving this the architect examined the traditional and local approaches synonymous with Congo and applied them with a blend of modern construction method and materials. The benefit of the approach to the design was that all aspects of sustainability in terms of environmental and social requirements were achieved as the building blended with the local architecture and could not be regarded as an imported architecture. The building showed the importance of generating local data to solve sustainability problems in the built environment.

Architect Paul Dequeker, who wrote the famous book "Tropical Architecture, Theories and Implementation in Tropical Humid Africa (1992), identified the two Sabena residential towers as" the best that could be seen in terms of 'local architecture in Kinshasa' (Lagae, 2014). The Congolese who live in the building did not complain and it could be observed that long after its construction, the building did not undergo any modifications. It can be concluded that on the spatial organization, the buildings remain truly Congolese, as Laurens planned.

\section{References}

Boghemans, G. (1921). L'habitation coloniale, in la cité, revue mensuelle belge, numéro 6, Iie année, édition Tekhné, mai, pp.139-46

Bruyère, M. (1952). « Contribution à l'étude des Habitations pour Indigènes au Congo Belge » Institut Royal Colonial Belge Section des Sciences Techniques Mémoires. — Collection in-S». Tome VII, fasc. 2.

Dequeker, P., \& Kanene, M. (1992). L'architecture tropicale: théorie et mise en pratique en Afrique tropicale humide, Kinshasa: Centre de recherches pédagogiques.

Heymans, M., Ricquier, G., Jean, G., \& Van, M. (1949). l'Urbanisme au Congo belge, Edition les Visscher, Ministère des colonies, Bruxelles Belgique

Hubin, M. (2002). Claude Strebelle, rêves et art de construire, éditions Luc Pire/Liège province Culture.

Lagae, J., \& Laurens, C. (2001). Claude Laurens: architecture: projets et réalisations de 1934 à 1971 . Gent: Vakgroep Architectuur en Stedenbouw, Universiteit Gent.

Lagae, J. (2014). De actualiteit van de architectuur van Paul Dequeker, Notities bij enkele projecten in kinshasa. In Dequeker, L., \& Neef, G. de (Éd.), (2014), Architectuur en missie in Afrika: het werk van broeder-architect Paul Dequeker scheutist. Leuven: KADOC

Laurens C. (1953). Vers une nouvelle architecture au Congo, in Bulletin de l'Union des Femmes Coloniales, Avril 1953,

Laurens, C. (1957a). Immeubles à Léopoldville, in Rythme n²3, Novembre, S.C.A.B, S.C.E.A, Bruxelles

Laurens, C. (1957b). Deux immeubles hauts à Léopoldville, Congo Belge, in architecture d'aujourd’hui, n²8, p. $22-23$

Lecoq, H. (1840). De géographie physique et de météorologie, ou résumé des notions acquises sur les grands phénomènes et les grandes lois de la nature, ed. Société typographique belge Bruxelles.

Liébard, A., \& De Herde, A. (2003). Guide de l'architecture bioclimatique: Tome 3, Construire en climats chauds. Paris: Observ'ER.

Lonoh, M. B., \& Ortolani, S. (dessins). (1977). Essais d'architecture authentique en République du Zaïre: Sante Ortolani 1972-1976, mise en page par Arch. Sandro Signa et Armando Ortolani, Tipolitografia A. Pucci, Rome.

McQuillan, T. (2016). On the Grounds of Modern Architecture: An Interview with Kenneth Frampton. Architectural Histories, 4(1), 20, 1-5. http://dx.doi.org/10.5334/ah.231

Olgyay, V. (1963). Design with Climate Bioclimatic Approach to Architectural Regionalism, Princeton University Press; $p$.

Pinol, J. L. (éd). (2003). Histoire de l'Europe urbaine, coffret 2 volumes. Paris : Seuil.

Royer, J. (1932). l'urbanisme aux colonies et dans les pays tropicaux, communications \& rapports du congrès international de l'urbanisme aux colonies et dans les pays de latitude intertropicale, tome 1, 1932 ÉD. DELAYANCE, Belgique 
Rycke, J. P. De. (2010). Africanisme et modernisme, la peinture et la photographie d'inspiration coloniale en Afrique centrale, édition scientifique internationale, Bruxelles.

Sinou, A. (1993). Le Sénégal. In Soulillou, J., \& Doutreuwe Salvaing, F. (Éd.), (1993), Rives coloniales: architectures, de Saint-Louis à Douala (1. ed). Marseille: Paris: Editions Parenthèses; Editions de l'Orstom.

Spanner, E. (1932). L'urbanisme en Afrique Equatoriale Francaise Brazzaville p.160-162- in Jean Royer, l'urbanisme aux colonies et dans les pays tropicaux, communications \& rapports du congrès international de l'urbanisme aux colonies et dans les pays de latitude intertropicale, tome 1, 1932 ÉD. DELAYANCE, Belgique.

Wauters A. J. (éd.). (1893). « l'architecture nègre » in Le Congo Illustré, voyages et travaux des Belges dans l’Etat Indépendant du Congo, vol II, Belgique, Bruxelles.

\section{Copyrights}

Copyright for this article is retained by the author(s), with first publication rights granted to the journal.

This is an open-access article distributed under the terms and conditions of the Creative Commons Attribution license (http://creativecommons.org/licenses/by/4.0/). 